Anna KURZYDLOWSKA ${ }^{1}$

\title{
LEADERSHIP IN PROJECT MANAGEMENT
}

The goal of this paper is to indicate possible ways to improve leadership qualities in Project Management. The approach to leadership is changing. The traditional concept of leadership perceived as "command and control" gradually gives way to a new, more flexible approach, which requires - on the one hand - the ability to predict (looking ahead) and - on the other - "courage" to delegate powers and the ability to motivate a team. The paper analyses two different approaches to leadership: transactional vs. transformational.

The results of the studies prove that a modern leader should be a transformational rather than a transactional one. Transformational leadership is about making all project members creative, engage and full of initiative. It is project manager role as leader to integrate team members around defined goals and make them feel responsible for solving project problems. In regard to growing demand for versatility of Project Manager, a Project Manager has to continuously improve his/ her leadership skills.

The author of this article, basing on her years' long experiences with running projects, formulates a recommendation concerning three ways of improving one's leadership skills. All three recommendations are practical and are aimed at helping Project Manager in engaging project team members in a joint effort to overcome difficulties, as well as looking for new challenges.

Keywords: Project Management, transactional leadership, transformational leadership, project leadership.

\section{INTRODUCTION}

Project management is not just the application of a suitable methodology. Project management is a combination of art and science, leadership and management ${ }^{2}$

Project Manager must look in various directions (see Figure 1). She/ he has to "look ahead" by planning project tasks and assigning resources. Project Manager's responsibility is to prepare a detailed schedule that will be used to control project progress. "Looking back" is not only monitoring project progress (in terms of timing, project scope, resources utilization and project quality) but also valuable learning from experience.

The famous quotation by Tom DeMarco and Tom Lister is that "Risk management is Project management for adults"3. One of Project Manager's task is to constantly

\footnotetext{
${ }^{1}$ Anna Kurzydłowska, Ph.D., PMP, PRINCE2 Practitioner, SCPM тм, e-mail:

a.kurzydlowska@uksw.edu.pl, Faculty of Mathematics and Natural Sciences, Institute of Computer Science Cardinal Stefan Wyszynski University in Warsaw, ul. Wójcickiego 1/3, 01-938 Warszawa. ${ }^{2}$ M. Arora, H. Baronikian, Leadership in Project Management- Leading People and Projects to Success 2013; $2^{\text {nd }}$ edition.

${ }^{3}$ T. DeMarco, T. Lister, Waltzing with Bears: Managing Risk on Software Projects 2013; Addison Wesley Professional.
} 
monitoring progress of mitigation actions in order to avoid risks, as well as to monitor positive ones which may turn into opportunities.

Whereas the ways to manage these four challenges (planning, controlling, managing risk - negative and positive one) have been described in detail with the use of formal project management methods, such as PRINCE2 ${ }^{\mathrm{TM}}{ }^{4}$ or $\mathrm{PMI}^{5}$, then there is no formal methodology defining methods, standards, and procedures to assist human resources management. These project management fields are about:

- managing project team - "Looking down"

- $\quad$ managing stakeholders - i.e. sponsors of the project - "Looking up" as well as clients, users, contractors and subcontractors - "Looking outside"

but also

- managing yourself as project manager and leader - "Looking inside"

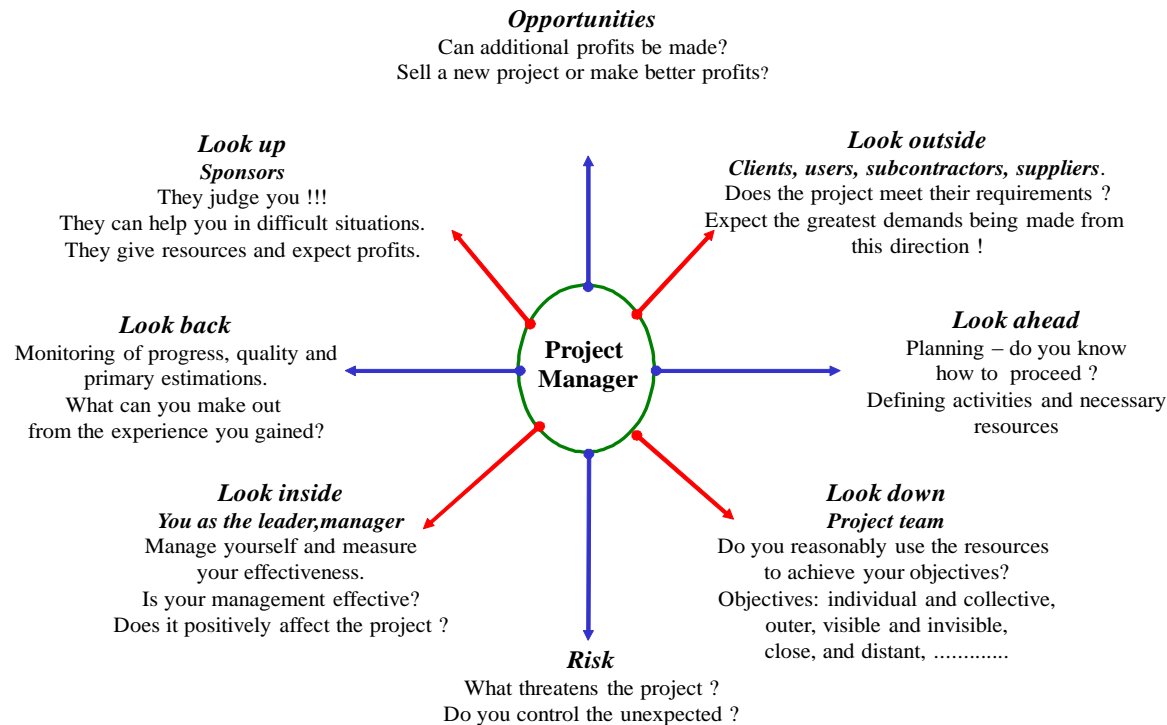

Figure 1 Project Manager must look in different directions (own source)

Tom DeMarco and Tim Lister ${ }^{6}$ claim that the success of the project depends, to a large extent, on the elements of project management, which cannot be learned on courses. Methods of managing a team, ways of communication with persons engaged in the project (up, down and in all other directions) are some of these elements.

\footnotetext{
${ }^{4}$ Office of Government Commerce, (2009), Managing Successful Projects with Prince2 ${ }^{\circledR}$ Manual

${ }^{5}$ D. Haughey, The Project Management Body of Knowledge (PMBOK)2013.

${ }^{6}$ T. DeMarco, T. Lister, Peopleware: Productive Projects and Teams, Addison Wesley 2013; 3 edition
} 
Yet, some qualities, rules of conduct making a good leader may be formulated. It must be emphasized, though, that these demands evolve constantly following the changes in the external conditions.

The conclusions made by the Author are based on her participation in a large number of IT projects which, among others, were implemented in the companies from following industries:

Banking, Insurance, Telecommunication, Public sectors. Projects value ranges from $\$$ 100000 to $\$ 65500000$ with average value of \$ 3000000 .

Research methodology was based on:

a more than 40 IT projects conducted by the Author working (for over 20 years) as Project Manager and Project Director in the biggest multinational information technology and consulting corporations

more than 15 Lessons Learned gathered by the end of IT projects shared by other Project Managers and Projects Reviews performed while working as Programme Management Office Manager

a about 50 Quality Assurance Reviews of IT projects done as Quality Assurance Specialist in big IT Company.

The structure of the paper is following. In the next section, two different approaches to leadership are presented followed by discussion (section 3 ) of qualities of modern leader/ project manager. Section 4 describes recommendations for how to improve leadership qualities. Last section of this paper contains conclusions.

\section{REVIEW OF TWO DIFFERENT APPROACHES TO LEADERSHIP}

The approach to leadership is changing. The traditional concept of leadership perceived as "command and control" gradually gives way to a new, more flexible approach, which requires - on the one hand - the ability to predict (looking ahead) and - on the other - "courage" to delegate powers and the ability to motivate a team.

\subsection{Transactional leadership}

This kind of leadership, popular in the 70s, derives from the military. Managing human resources was based on giving commands and controlling their execution. Such an approach results from the leaders' belief that:

- $\quad$ They are always right; they have a suitable solution to each problem

- $\quad$ They should stand above and in no way get emotionally engaged in the group relations

- $\quad$ They should never admit failure

- Work is the most important thing, even at the cost of the family

- $\quad$ Team members work effectively only when they are accordingly manipulated, rewarded and punished

- $\quad$ Criticism is the best way to get things done properly

- Group conflicts should be resolved with a competitive win-lose approach, not a win-win one

- Having power is the clue

- $\quad$ People are natural-born leaders. 
This approach had its positive sides. Leaders with such attitudes achieved success due to their enormous engagement and determination in goal attainment. Transactional leadership produced a specific culture within the company. Promoting a win-lose philosophy and creating barriers among people, underestimating employees' unique abilities and predispositions - were elements of this culture. Consequently, organizations and groups of this type were usually very bureaucratic, rule- and procedure-oriented, creating the atmosphere of frustration and discontent.

To sum up - traditional leaders with transactional leadership approach attain the intended results by defining goals and rewarding, depending on the degree of their attainment. This kind of leadership consists in planning, controlling and appropriately selected motivating. It seems that in the past such skills in management were useful. Yet, in the dynamically changing today's reality they are not sufficient.

\subsection{Transformational leadership}

A decisive factor determining the success of the project, in the constantly changing environment and the client-oriented approach, is the adjustment of the leaders' activities to these new challenges. Their success will be, to a large extent, the result of specific qualities of a "transactional leader" plus a flexible adjustment to new challenges via:

- $\quad$ Making all project members creative, engaged and full of initiative.

- $\quad$ Integrating team members around defined goals and making them feel responsible for solving everyday problems.

The skills of Project Manager should be built upon traditional features and supplemented with the following elements.

- $\quad$ Ability to formulate and communicate the project objectives.

- Ability to convince all team members to realize their individual goals, consistent with the general objective.

- Ability to listen to others and to find solutions basing on their suggestions.

Ability to create atmosphere allowing team members to freely evaluate the work of the team and Project Manager and to get a feedback delivered in an assertive way. negative ones.

Ability to admit mistakes and to learn from experiences, also the

- $\quad$ Ability to cope with conflict situations.

- $\quad$ Ability to build relations encouraging cooperation and mutual support. project procedures.

Ability to manage the performance of tasks and not the performance of

\section{QUALITIES OF A MODERN PROJECT LEADER/ MANAGER}

The importance of leadership as one of a characteristic of project manager behavior is a young subject in PM discipline. The first results of studies on connection between different leadership styles and project success in specific types of projects were published just around 2006.

The qualities we expect to see in a leader/project manager today are more abstractive and unmeasureable than the ones traditionally centered around the accomplishment of a 
project objective. According to the survey conducted by Sporting Bodymind Ltd. (sycon.uk.com) a true leader should:

\section{a. Positively affect the team with her/his attitude}

On the one hand, the leader should arouse respect, admiration and trust among subordinates, while on the other, serve as an example of highly ethical and moral behavior. He/she should not be afraid of facing risk, yet should avoid abusing authority and power for individual purposes.

One can say, that a charismatic leader should be

- $\quad$ chic - he/she should be flexible in adoption of new methodologies/ tools, but does not uncritically workship new trends;

- $\quad$ clear - says what he/she means, clearly expresses opinions;

- $\quad$ clever, competent - well-prepared but not big-headed;

- $\quad$ creative - think up innovative solutions;

- $\quad$ crisp - to the point;

- $\quad$ concise - concentrates on the issue, is not wordy;

- $\quad$ confident - knows what he says, speaks seriously;

- $\quad$ consistent - makes his stand clear and sticks to it;

- $\quad$ controlled - does not panic, knows the issue;

- $\quad$ curious - open-minded.

These qualities are grouped and described in table 1.

Table 1 Charismatic leader qualities (own source)

\begin{tabular}{|l|l|l|}
\hline Chic & Innovative & be ,cutting edge” (not trendy) \\
\hline Clear & Coherent & say what you mean \\
\hline $\begin{array}{l}\text { Clever } \\
\text { Competent }\end{array}$ & Smart & be well prepared, not "foxy" \\
\hline Creative & Inventive & think up innovative solutions \\
\hline Crisp & To the point & the first impression is important \\
\hline Concise & Brief & be focussed, don't waffle \\
\hline Confident & Self-assured & mean what you say \\
\hline Consistent & Consequent & define your path \& stick to it \\
\hline Controlled & Calm & don't flap - know your stuff \\
\hline Curious & Open-minded & be intelligent, never arrogant \\
\hline
\end{tabular}

\section{b. Motivate in an inspiring way}

"To inspire" means to motivate each group member to raise above individual interests and to act in the interest of the collective. This kind of motivating puts emphasis on the tasks being carried out, as well as on providing a positive vision of the future. Managers who stick to this attitude ooze with optimism and enthusiasm, which elicits additional effort from the subordinates. 


\section{c. Stimulate intelectually}

The Project Manager's stimulating behavior motivates the staff to look for new solutions while solving old problems. This approach promotes creativity and taking risk. It requires from the leader an appropriate attitude in the case of more than frequent failures and under-achievements.

\section{Taking individualized approach}

New approach leaders recognize the needs and potential of individual group members in order to take an individualized approach towards each of them. They aim at discovering specific abilities of particular persons. They set challenges, enable team members to broaden their knowledge by learning, but also by coaching. It is supported by a more personalized approach to the staff.

Independent survey conducted in the $\mathrm{US}^{7}$ point to similar qualities of a modern leader. The survey is based on experiences of several hundred persons. Each surveyee was asked to pick a project, program or significant event, which would be classified as his/her best experience in leadership. Some of the survey questions included:

ii. What made you hope you would achieve desired results?

iii. How did you manage to engage particular persons into the project?

iv. What methods did you use to encourage co-workers to make additional efforts and accomplish the goal?

v. What leadership experience did you gain from the project?

Despite differences between the projects and their conditions, some qualities making a good leader were clearly pointed out. According to Kouzes and Posner, when getting extraordinary things done in organizations, leaders engage in Five Practices of Exemplary Leadership:

1. Model the way - set challenges, look for new solutions

Leaders look for new solutions to problems and methods to improve the organization. In this way they take some risk of experimenting, yet they know it may be a source of mistakes and failure. They are prepared for disappointment and accept it positively, treat it as learning by mistakes.

2. Inspire a Shared Vision -provide a vision for the future and inspire

Leaders believe that their actions have a deeper meaning and add to the value of organization/society/group of which they are members. They have a vision of the future, share it with others and inspire them. Using their charisma, they win support of team members who share their enthusiasm, positive, exciting look in the future.

3. Challenge the Process - motivate effectively

Leaders know how to build co-operative teams. They actively motivate others to actions and - if need be - to further efforts. Respect is a very important element. Atmosphere of mutual trust and respect is required. Each team member feels as important as others. He/she knows that his/her work is a significant input into the project and determines its success.

${ }^{7}$ J.M. Kouzes, B.Z. Posner, The Leadership Challenge, John Wiley \& Sons 2008, Fourth Edition 
4. Enable Others to Act - set directions, model solutions

Leaders should define the rules of cooperation of team members, as well as methods to achieve objectives. The basic method of setting standards is the leader's own conduct. It should serve as a model. At the same time, it is the leader's task to set objectives to the team members in such a way that the accomplishments of subsequent successes leads the whole group to the ultimate goal. The leader, basing on his/her knowledge, intuition, emotional intelligence should flexibly balance the degree of bureaucracy, formalism, particularity in setting objectives, freedom of action and delegating responsibilities.

5. Encourage the Heart - keep the spirit of the team high, appreciate, celebrate success.

Keeping up a good atmosphere, particularly when the project is at the crossroads, is not easy. It is the leader's role to sustain positive thinking. Positive motivation rewarding, appreciating, celebrating success - is very important. These and other methods help to raise self-esteem of team members and the team as a whole.

The surveys conducted show that the most effective leaders exhibit qualities of both the transactional and transformational leaders. Consistently, those more transformational are more effective than those more transactional. Different researchers confirm also that:

1. One-year-survey in a group of 78 managers from Canadian financial institutions supported a thesis that leaders with transformational qualities add to team/company success more frequently than transactional leaders ${ }^{8}$

2. Hay $\mathrm{McBer}^{9}$ has shown that $28 \%$ of variance in business success can be attributed to organizational climate. $70 \%$ of organizational climate is attributed to leadership style. Leadership style is the consistent use of leadership competencies

3. The project manager's competency, which includes his or her leadership style, is positively correlated to project success ${ }^{10}$. They also found that transactional style of leadership is good for simple engineering projects, while transformational style is better for more complex projects.

4. Dominick, P,. Artonson, Z., and Lechler,T. ${ }^{11}$ found a correlation between transformational style leadership and project success

5. Successful project managers, according to a survey conducted in 28 organizations, were evaluated as more transformational leaders than those who managed a project delayed in time, either due to budget or quality problems

6. Surveys confirming the above remarks have also been conducted in Japan, Singapore, Spain, Italy, France, US, UK, New Zealand and Canada.

7.

\footnotetext{
${ }^{8}$ J.M. Howell, B.J. Avolio, Transformational leadership, transactional leadership, locus of control and support for innovation. Journal of Applied Psychology 1993, 78, 891 - 902.

${ }^{9}$ H. McBer, Managing for Performance Improvement, Boston 1996, Hay MacBer.

${ }^{10} \mathrm{R}$. Turner, R. Muller, Choosing Appropriate Project Managers: Matching Their Leadership Style to the Type of Project, 2006 Project Management Institute.

${ }^{11}$ P. Dominick, Z. Aronson, T. Lechler, Transformational leadership and project success. R. R. Reilly (Ed.), The human side of project leadership 2007 (pp. 1-30) Newton Square, PA: Project Management Institute.
} 


\section{RECOMMENDATIONS AS HOW TO IMPROVE PROJECT LEADERSHIP QUALITIES}

"A superior leader is a person who can bring ordinary people together to achieve extraordinary results" (Unknown)

One can distinguished three ways to improve imperfect leadership conduct:

$>$ learning by doing,

$>$ learning from others,

$>\quad$ learning in the classroom or on your own.

Beneath you will find examples making it possible to improve or to develop the first quality of a modern leader/ project manager, i.e. the ability to constantly take up challenges and to look for new solutions.

- Learning by doing

- $\quad$ Express your readiness to undertake difficult projects; actively search for new challenges, even if it requires much of your effort.

- Prepare a things-to-do list taking into account current situation of the project; remember to ask - concerning every task on the list - "Why am I doing it? Maybe this task may be skipped or done in a much better way?"

Start each project team meeting with the question: "What actions, which significantly improved your effectiveness, have you started in the previous week?" Consequently ask the same question for three weeks during the following meetings with your team. It will make your staff realize how important this issue is to you. Yet, be prepared to answer the question yourself.

Do not make your weekly project meetings with the team a reporting on the current situation and responsibilities of particular persons. Devote some time to discuss ways of improving the way project tasks are done.

If you have doubts concerning the policy or procedures that we apply in the project - ask "Why are we doing it in this way?". If you get the answer "Because we have always been doing so", suggest changes to organize it in the best possible way.

Do not forget to meet each person from project team - it is important. At the meetings ask: "What really disturbs them (if any) in the project group ?" If possible, promise them you would remove the most frequent obstacles.

Discover new ideas. Search for them in other projects (inside or outside your company). Do not give up in looking for new solutions, which can positively influence the project you are managing.

Reward risk-takers. Appreciate them. A chance to tell about one's success is also a reward. You will win the support of innovative thinking enthusiasts.

Stick to your beliefs even if you are in minority.

- $\quad$ Learning from others

- $\quad$ If - in your company - there are people you perceive as good project managers, try to talk to them. Ask how they managed to achieve it.

- $\quad$ Read biographies of people successful in business, science, politics or some other field. Draw conclusions, which may help you to make a good leader/ project manager.

- Learning in the classroom or on your own 
At the end, I would like to quote Carly Fiorina, HP CEO, who - in her speech at the MIT, June 2, $2000^{12}$ - remarked:

"Leadership in this new landscape is not about controlling decision-making. We don't have time anymore to control decision-making. It's about creating the right environment. It's about enablement, empowerment. It is about setting guidelines and boundaries and parameters and then setting people free.

Leadership is not about hierarchy or title or status; it is about having influence and mastering change. Leadership is not about bragging rights or battles or even the accumulation of wealth; it's about connecting and engaging at multiple levels. It's about challenging minds and capturing hearts. Leadership in this new era is about empowering others to decide for themselves. Leadership is about empowering others to reach their full potential. Leaders can no longer view strategy and execution as abstract concepts, but must realize that both elements are ultimately about people."

\section{CONCLUSIONS}

The analysis of two approaches to leadership (i.e. transactional vs. transformational), in regard to growing demand for versatility of Project Manager, points to the necessity of continuous improvement of one's leadership skills.

The results of the studies prove that a modern leader should be a transformational rather than a transactional one. Transformational leadership is about making all project members creative, engage and full of initiative. It is project manager role as leader to integrate team members around defined goals and make them feel responsible for solving project problems

The author of this article, basing on her years' long experiences with running projects, formulates a recommendation concerning three ways of improving one's leadership skills. All three recommendations are practical and are aimed at helping Project Manager in engaging project team members in a joint effort to overcome difficulties, as well as looking for new challenges.

\section{LITERATURE}

[1] Arora M., Baronikian H., (2013) Leadership in Project Management- Leading People and Projects to Success; $2^{\text {nd }}$ edition

[2] DeMarco T., Lister T,. (2013) Waltzing with Bears: Managing Risk on Software Projects; Addison Wesley Professional

[3] DeMarco T., Lister T. (2013), Peopleware: Productive Projects and Teams, Addison Wesley; 3 edition

[4] Dominick, P., Aronson, Z., Lechler, T. (2007), Transformational leadership and project success. R. R. Reilly (Ed.), The human side of project leadership (pp. 1 30) Newton Square, PA: Project Management Institute

[5] Fiorina C. (2000), Massachusetts Institute of Technology Commencement, Cambridge, Massachusetts

[6] Haughey D., (2013), The Project Management Body of Knowledge (PMBOK)

\footnotetext{
${ }^{12}$ C. Fiorina, Massachusetts Institute of Technology Commencement, Cambridge 2000, Massachusetts.
} 
[7] Kouzes, J. M., Posner B. Z., (2008), The Leadership Challenge, John Wiley \& Sons, Fourth Edition

[8] Howell, J.M., Avolio B.J. (1993), Transformational leadership, transactional leadership, locus of control and support for innovation. Journal of Applied Psychology, 78, 891 - 902

[9] McBer H. (1996), Managing for Performance Improvement, Boston, Hay MacBer

[10] Office of Government Commerce, (2009), Managing Successful Projects with Prince2 ${ }^{\circledR}$ Manual

[11] Turner R., Muller R. (2006) Choosing Appropriate Project Managers: Matching Their Leadership Style to the Type of Project, Project Management Institute.

\section{PRZYWÓDZTWO W ZARZACDZANIU PROJEKTAMI}

Celem artykułu jest wskazanie możliwych sposobów doskonalenia zdolności przywódczych Kierowników Projektów.

Podejście do przywództwa zmienia się. Można mówić o zmianach przywództwa z tradycyjnego bazującego na stylu "poleceń i kontroli" w nowe - bardziej elastyczne. wymagające $\mathrm{z}$ jednej strony zdolności do przewidywania (spojrzenia w przód) a $\mathrm{z}$ drugiej strony "odwagi" w delegowaniu uprawnień i zdolności do motywowania zespołów. W artykule analizowane są dwa podejścia do przywództwa - tradycyjne (ang transactional) i transformacyjne (ang. transformational).

Wyniki badań pokazują że współczesny lider powinien być bardziej transformacyjny niż tradycyjny w podejściu do przywództwa. Przywództwo transformacyjne polega między innymi na stworzeniu warunków, w których wszyscy biorący udział w projekcie wykazują się inicjatywą, kreatywnością i zaangażowaniem. Jednym z zadań Kierownika Projektu jest zintegrowanie członków zespołu wokół uzgodnionych celów tak by czuli się oni aktywnie współodpowiedzialni za rozwiązywanie codziennych problemów. W kontekście coraz większych wymagań na wszechstronność współczesnego Kierownika Projektu, analiza tych dwóch podejść wskazuje na konieczność ciągłego ulepszania zdolności przywódczych.

Autor artykułu, bazując również na swoich wieloletnich doświadczeniach z prowadzenia projektów formułuje rekomendacje dotyczące trzech sposobów poprawienia zdolności przywódczych Kierowników Projektów. Wszystkie rekomendacje mają wymiar praktyczny i w swojej wymowie mają pomóc Kierownikowi Projektu w zastanowieniu się w jaki sposób zaangażować członków zespołu projektowego we wspólne pokonywanie trudności jak i wspólne poszukiwanie nowych wyzwań.

Słowa kluczowe: Zarządzanie projektami, przywództwo tradycyjne, przywództwo transformacyjne, przywództwo w zarządzaniu projektami.

DOI:10.7862/rz.2016.hss.22

Przesłano do redakcji: listopad 2015

Przyjęto do druku: czerwiec 2016 